\title{
EFFECT OF BRAND VALUE ANNOUNCEMENTS ON STOCK RETURNS: EMPIRICAL EVIDENCE FROM TURKEY
}

\author{
Pinar BASGOZE ${ }^{1}$, Yilmaz YILDIZ ${ }^{2}$, Selin METIN CAMGOZ ${ }^{3}$ \\ Department of Business Administration, Faculty of Economics and Administrative Sciences, \\ Hacettepe University, Beytepe-06532, Ankara TURKEY

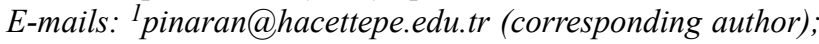 \\ 2yilmazyildiz@hacettepe.edu.tr; 3selinm@hacettepe.edu.tr \\ Received 18 June 2015; accepted 09 February 2016
}

\begin{abstract}
This study examines the effects of brand value announcements on stock returns of Turkish firms by using the event study methodology and long-term risk adjusted portfolio returns. We examined the stock-price impacts of 299 brand value announcements on the stock market performance of the firms within the years of 2010-2014 by using BrandFinance Turkey's 100 ranking list as a data source. The findings indicate that the companies listed in the Turkey Top 100 Brands list earn positive abnormal returns 7 months after the announcement. Similarly, the companies which had greater brand values relative to the previous year, experienced significant positive abnormal returns in the 7-months period. Additional findings suggest that investors are able to beat the market in the long run regarding risk-adjusted returns by consistently investing in the Top Brands. Overall, the study demonstrates new evidence to the marketing-finance interface by focusing on the Turkish case as an important emerging market.
\end{abstract}

Keywords: brand value, brand value announcement, stock returns, event study analysis, emerging markets, Turkey.

JEL Classification: M31, D53, G14.

\section{Introduction}

Maximizing future returns of stockholders and thereby increasing the market value of the firm is one of the main financial aims of enterprise management. Although the exploration of "which tangible assets contribute more to value generating" constitutes the essential theme in traditional financial management (Fama, Miller 1972), intangible assets are also important instruments for the long-term financial performance of firms (Edmans 2011; Wang et al. 2015). Almost two decades ago, Day and Fahey (1988) gave importance to intangible measures such that: "managers of diversified companies are rapidly replacing their usual yardsticks of performance, such as market share, growth in sales, or return on investment, with approaches that judge market strategies by their abilities to enhance shareholder value". 
According to Osinga et al. (2011), the expected future value of a company's relevant cash flows reflects the firm's value which mostly depends on the marketing activities of the firm. Among those marketing proxies, product quality, customer satisfaction, and increasing market share are key intangible assets related to the financial performance of firms (Aaker, Jacobson 1994; Himme, Fischer 2014; Peterson, Jeong 2010; Verbeeten, Vijn 2010). More recently, scholars have given special attention to brand equity/value with the publication of Aaker's (1991) seminal work discussing the power of brands as an important intangible asset. Following this, brands are regarded as valuable because of their ability to maintain and create earnings for the firm over and above the earnings generated by tangible assets (Lane, Jacobson 1995).

As brand equity is seen as a key concept in generating future earnings streams, scholars have started to test whether building strong brands may boost the stock market values through increasing the demand for products and services (Aaker 1991). Derived from this argument, this research responds to the need for empirical evidence about how marketing affects a firm's financial performance. In this vein, the current paper focuses on the effects of brand value announcements as a specific intangible asset-based valuation on firms' stock returns. It aims to test the stock price reactions to the brand value announcements of BrandFinance and assess the long-run performance of the firms included in the BrandFinance Turkey 100 list.

Conducting this research contributes to the literature in several ways. First and foremost, this study fills the gap in the literature by examining the relationship between brand value announcements and stock market performances of the firms by using a global brand-ranking list as a data source within the period 2010-2014. Although several scholars have reported the link between branding and financial performance (Barth et al. 1998; Belo et al. 2014; Hsu et al. 2013; Kerin, Sethuraman 1998), little systematic empirical work (Dutordoir et al. 2015) has addressed the issue of stock price reactions to brand value announcements. Second, the current study tests its hypotheses through the methodology of an event-study analysis. While a few studies explore the relationship between brand-equity measures and the financial performance, relatively sparse study has utilized the methodology of event study (Dutordoir et al. 2015). Third, the results generated from the current study provide valuable insights not only for researchers but also for both marketing and finance managers on the appropriateness of the brand value model in order to explain the future financial performance of the firms. Moreover, the findings are crucial as it offers special practical recommendations for investors who want to assess the creation of shareholder wealth in the long term. Last but not least, we present new evidence and thus contribute to the marketing-finance interface by focusing on the Turkish case, which is considered as an important emerging market.

This paper is organized as follows. We briefly discuss the related literature in the next section and form the hypotheses of the study. Then, we include the empirical study and the findings. The study contains a discussion of the results, conclusions and limitations at the end. 


\section{Literature review}

\subsection{Brand value}

The concepts of brand equity and brand value are used interchangeably in most research, the operationalization of brand equity involves the two valuation techniques of either consumer or financial-based suggestions for measuring brand equity (Cobb-Walgren et al. 1995). According to the consumer-based perspective, brand equity is defined as "the set of associations built, in the image of the consumer that allow the brand to generate a greater turnover than it would if the product did not have that brand" (Calderon et al. 1997: 294). It is the set of brand assets and liabilities that are linked to a brand's name and symbol (Verbeeten, Vijn 2010). It consists of brand elements such as brand awareness, brand associations, and marketing assets that help distinguish one brand from another in the eyes of the consumers (Keller 2003; Tiwari 2010). According to the financial-based perspective, brand value is defined as "the tangible wealth emanated from the incremental capitalized earnings and cash flows achieved by linking a successful, established brand name to a product or service" (Kerin, Sethuraman 1998: 262). It is based on the difference between net present value of future cash flows from a branded product's revenue and the revenue of an unbranded product (Tiwari 2010). Stated simply, brand equity is closely related to a customer perspective while brand value is related to a financial perspective (See Tiwari 2010). The BrandFinance ${ }^{1}$ database, used in the current study, rests its evaluations through the mixture of financial and consumer-based perspectives as the company argues that discrete evaluations of consumer or financialbased perspectives solely are insufficient in brand valuation (Davis 2010).

\subsection{Brand value and financial performance}

The most familiar empirical research of Aaker and Jacobson (1994), examining the annual stock returns of 34 global brands owner firms between 1982-1992, demonstrated that firms with the largest gains in their brand value measure experience average returns of $30 \%$ while firms with diminished brand value experience $10 \%$ loss. Copraro and Srivastava (1997) investigated the market-to-book ratios of Fortune 500 companies, with results suggesting that more than $70 \%$ of the market value of those companies lies in intangible assets. Moreover, Barth et al. (1998) discovered that brand valuations announced by consulting firms are relevant in share prices. By examining 183 publicly traded US firms from 1991 to 1996, the findings revealed that brand value is positively associated with advertising expenses and market shares. Likewise, Kerin and Sethuraman (1998) reported a positive association between financial brand values and market-to-book ratios by investigating the American companies of the 1995-1996 Interbrand Most Valued Brands. Similarly, de Mortanges and Riel (2003) examined the effect of brand value for a number of Dutch companies on the firm value within a period of 1993-1997. Their findings demonstrated that brand value has a significant effect on the value of the firm.

\footnotetext{
${ }^{1}$ BrandFinance use a royalty relief approach, which discounts the future expected cash flows attributed to the brand. This valuation methodology involves many steps and explained further in the methodology part.
} 
The study of Dutordoir et al. (2015) reported the evidence of significant stock price reactions to the Interbrand brand value changes. Similarly, by using the stock returns for the period 1994-2000, Madden et al. (2006) noted that strong brands not only deliver greater returns to stockholders than a relevant benchmark but also do so with less risk. The meta-analysis of Conchar et al. (2005) supported the linkage between a firm's brand-building activities and the financial performance of the firm. Correspondingly, Eng and Keh (2007) reported the financial brand value as a variable that explains future ROA and stock returns of the firms. Recently, some other scholars (Baharadwaj et al. 2011; Johansson et al. 2012) found that perceived brand quality has significant effects on financial metrics of the firms. Likewise, Verbeteen and Vijn (2010) demonstrated that financial brand value is an antecedent of financial performance including cash flow, stock prices or market share.

To summarize, the brand equity models provide evidence that branding creates tangible financial outcomes that should have positive financial effect on the share prices of a company. Like other forms of investment, expenditure on building a brand value improves shareholder value and it provides marketers a justification that brand investments have the required pay-off (Yeung, Ramasamy 2008). That is why stock market returns increase when brand values as determined by independent agencies increase (Hsu et al. 2013; Kallapur, Kwan 2004). So, we propose that the stock returns of the companies that are listed in BrandFinance Turkey 100 are greater compared to the firms that are not listed in BrandFinance Turkey 100 list. Thus;

H1: Following the announcement, the stock returns of the firms that are listed in BrandFinance Turkey Top 100 Brands are greater compared to the firms that are not listed in BrandFinance Turkey 100.

In addition to our main hypothesis, we also explore some supplementary propositions. Prior studies on the index addition case provide evidence of the increased investor awareness for the stocks added to the index which might advocate the Merton's (1987) model of market segmentation (Dhillon, Johnson 1991). If investors hold only the stocks that they are aware of, they will demand a "shadow cost" for imperfect diversification and increased systematic risk. If a stock's addition to the Brand Value list increases the awareness of the investors on this stock, the required rate of the stock will consequently decline due to decrease in the shadow cost. On the other hand, close monitoring of the investors will force the newly added firms to avoid inefficient investments and motivate them to make value-enhancing decisions (Denis et al. 2003). Based on those, we expect that newly added stocks will earn positive abnormal returns due to decreased shadow cost.

H2: The firms, which are newly added to the Turkey Top 100 Brands list, experience positive abnormal stock returns.

After proposing the impact of brand value announcements on the stock performance of the newly added firms, it seems noteworthy to investigate the plausible effects of value and ranking changes in the Top Brands list within announcement periods. In order to test the effect of brand value appreciation or depreciation on future stock returns, we propose: 
H3a: Firms with greater brand values compared to the previous year experience positive abnormal stock returns.

H3b: Firms with lower brand values compared to the previous year experience negative abnormal stock returns.

Like greater brand values, brand ranking might also act as a proxy for other firm characteristics that may lead to share price over-performance. Brammer et al. (2009) highlight that the firms improved their rankings enjoy strong stock returns. Thus, we propose:

H4a: Firms with greater brand rankings compared to the previous year experience positive abnormal stock returns.

H4b: Firms with lower brand rankings compared to the previous year experience negative abnormal stock returns.

According to DeBondt and Thaler (1985)'s overreaction-underreaction theory, most of the time investors in the stock market overreact to new information, causing the security's price to change dramatically so that the price will not fully reflect its true value immediately following the event. However, this price shift from overreaction is not permanent because the stock price will tend to return back to its true value over time. In congruent with overreaction theory, Brammer et al. (2009) indicate that firms being added to the list or improve their rankings enjoy strong stock returns but continued inclusion in the list year after specific year is associated with negative abnormal returns. Thus, we propose:

H5a: Consistently investing in high brand value firms generates positive abnormal returns in the long run.

H5b: Consistently investing in the firms newly added to the Top Brands list generates positive abnormal returns in the long run.

\section{Methodology}

\subsection{Data sources}

The required data about the yearly brand rankings is obtained from the BrandFinance database, which is a private brand valuation consultancy agency, disclosing yearly brand rankings for many emerging and developed countries including Turkey. It announces and publishes the BrandFinance Turkey 100 list annually along with the scores and ranking of each firm for 5 years. The company bases its estimations through the mixture of financial and customer perspectives. For the current study, the Top 100 Brand Value data is available from 2010 to 2014 . Brand value ranking research is based on the accessible financial information and analysts' observations about the firms.

BrandFinance valuation methodology involves many steps. First, it calculates the brand strength of a company, ranging from 0 to 100, which is called as Brand Strength Index. Then, a royalty rate is calculated for the sector and also for each brand. By using the brand's historical revenues, growth rates, and analyst's opinions, the agency forecasts the future cash flows of the brand. Last, the royalty rate is applied to the forecasted 
cash flows to derive an implied royalty charge, and this royalty value is discounted to a net present value for each brand (BrandFinance 2013). Monthly stock price and index value data are obtained from the Finnet ${ }^{2}$ which is a private data vendor in Turkey. The detailed explanations about the techniques are stated in the following sections.

\subsection{Stock price reactions to brand value announcements}

To test the stock price reactions to the brand value announcements, we applied event study methodology over 10 months post-event period; including the month that the announcement takes place. We determined our event window as $[0,10]$ months, since the announcement month of Turkish firms' brand rankings varies from year to year, deciding 10-months event period avoids any overlap of announcement effects.

The classical event study methodology follows 3 steps. In the first step, we calculated abnormal returns as follows:

$$
A R_{i, t}=R_{i, t}-R_{m, t} .
$$

$A R_{i, t}$ stands for the abnormal return of the $\mathrm{i}^{\text {th }}$ stock in time t. $R_{i, t}$ and $R_{m, t}$ are the return of the $i^{\text {th }}$ stock and return of the market in time t, respectively. The return of the local BIST100 index is used for the market return. In the second step, we calculated the average abnormal returns (AAR) for each firm in our sample, as follows:

$$
A A R i, t=\frac{1}{N} \sum_{i=1}^{N} A R i, t .
$$

In the final step, in order to see the aggregate effect of the event, we take the sum of the AAR values to obtain the cumulative average abnormal return (CAAR) for each day in the event window, formulated as:

$$
C A A R i, t=\sum_{t=1}^{N} A A R i, t .
$$

To assess the significance levels of our results, we used conventional t statistics.

It is important to allow for firm characteristics when investigating the performance of "100 Best Brands" since the firms with high brand value are large and growth stocks. Thus, we intended to analyze the impact of firm characteristics on cumulative abnormal returns 10 months after the announcement. In other words, we try to answer the following question: "Is this abnormal return that was observed up to 10 months after the brand value announcements has already emerged due to existing firm characteristics?". In order to answer this question, we conduct the following methodology.

As an indicator of the impact of being in Top 100 Brands list, we regress cumulative abnormal returns in 10 months after the announcement ("CAR") on a dummy variable taking the value of 1 if the firm is in the Top Brands list and 0 otherwise ("BRAND").

\footnotetext{
${ }^{2}$ FINNET stands for Financial Information News Network. This is a database company, which develops research and analysis tools for capital and money markets in order to meet information needs of institutional and individual users.
} 
This regression includes all firms in Top Brands list whose data is available plus the firms stated in BIST100 Index but not included in the Top Brands list during the 4 years period. We employ a pooled regression including the year dummies in the model. We also include the market value of the firm (" $C A P$ ") and market-to-book ratio ("Mt $B$ ") prior to the announcement. The statistical expression of the equation is as follows:

$$
\begin{aligned}
C A R i, t= & \beta 1 B R A N D i, t+\beta 2 C A P i, t+\beta 3 M t B i, t+\beta 4 D 2010+ \\
& \beta 5 D 2011+\beta 6 D 2012+\beta 7 D 2013+u i, t .
\end{aligned}
$$

\section{Long-run performance of the firms included in the Top 100 Brands list}

In order to assess the long-run performance of the firms included in the BrandFinance Turkey 100 list, we implement an investment strategy by forming various portfolios by updating the portfolio every year after the announcement. There is an ongoing debate considering whether buy and hold or cumulative abnormal returns are appropriate to calculate the long-run returns. According to the famous paper of Fama (1998), in order to minimize the "bad model problem" and avoid any misleading and spurious abnormal returns, rather than buy and hold returns, cumulative abnormal returns should be used to calculate long-run excess returns. Therefore, we calculated the average abnormal returns separately for each month and aggregated monthly returns to get cumulative average abnormal returns in the long run. The formulas related to the calculation of $A A R$ and $C A A R$ were explained in the previous section.

As there is not a common agreement in the literature as to whether equal-weighted or value-weighted portfolios are more appropriate regarding reliable investment strategies, we utilized both of the approaches together. Different than an equal-weighted portfolio, a value-weighted portfolio gives less weight to the stocks with lower brand values.

According to the modern portfolio theory, an investor has to take more risk to get more return. Risk and return should be combined to assess the performance of any portfolio. To this end, we also calculated 3 risk-adjusted performance measures for all portfolios and compared their performances with the benchmark portfolio (BIST100 Index).

The Sharpe ratio (Sharpe 1994) measures the return of the portfolio in regard to its risk. This ratio uses standard deviation of the returns as the risk measure. The mathematical description of the ratio appears as follows:

$$
\text { Sharpe } \cdot \text { Index }=\frac{d i}{S d i} \text {. }
$$

In this formula, $d_{i}$ corresponds to the excess return of the portfolio over the risk-free rate. As a proxy for the risk-free rate, we used 10-years government bond yields for each month. $S d_{i}$ is the standard deviation of the monthly returns in the sample period. This ratio is appropriate if it is assumed that the analyzed portfolio is the only one that the investor holds.

Additionally, we used the Treynor ratio (Treynor 1965) to assess the reward of the portfolio in regard to its systematic risk. This ratio is appropriate if the analyzed portfolio 
is a well-diversified one, and it is not exposed to a firm's specific risk. Different from the Sharpe Index, it uses a stock's beta rather than the standard deviation to assess the riskiness of the portfolio. It is formulated as:

$$
\text { Treynor } \cdot \text { Index }=\frac{d i}{\beta} \text {. }
$$

Finally, we calculated Jensen's alpha to measure the long-run performance of the portfolios. It is used to calculate the abnormal return of the portfolio over the theoretical expected return (Jensen 1968) and is used in conjunction with the Sharpe and the Treynor Index and formulated as:

$$
\text { Jensen's } \cdot \text { Alpha }=R i-[R f+\beta(R m-R f)] .
$$

A positive Jensen's alpha implies that the analyzed portfolio returns are higher than expected.

\section{Findings}

\subsection{Event study results of price reactions to brand value announcements}

Table 1 presents the average abnormal returns (AAR), cumulative average abnormal returns (CAAR), and the significance levels of the abnormal returns for the event period lasting 10 months for all firms included in the BrandFinance Turkey Top 100 list. There are 299 firm-year observations ${ }^{3}$. We excluded the firms which are not traded in the stock market and having missing stock price information.

Table 1. Announcement window monthly abnormal returns of all firms

\begin{tabular}{ccccc}
\hline Period & AAR & t-stat & CAAR & t-stat \\
\hline 1 & -0.003 & $(-0.572)$ & 0.003 & $(-0.572)$ \\
\hline 2 & -0.008 & $(-1.358)$ & -0.011 & $(-1.417)$ \\
\hline 3 & -0.003 & $(-0.525)$ & -0.014 & $(-1.523)$ \\
\hline 4 & 0.006 & $(1.215)$ & -0.008 & $(-0.736)$ \\
\hline 5 & 0.005 & $(1.059)$ & -0.003 & $(-0.301)$ \\
\hline 6 & 0.010 & $(1.713)^{*}$ & 0.006 & $(0.509)$ \\
\hline 7 & 0.027 & $(4.763)^{* * *}$ & 0.033 & $(2.337)^{* *}$ \\
\hline 8 & 0.016 & $(1.978)^{* *}$ & 0.049 & $(2.950)^{* * *}$ \\
\hline 9 & -0.007 & $(-1.161)$ & 0.042 & $(2.418)^{* *}$ \\
\hline 10 & 0.019 & $(3.330)^{* * *}$ & 0.060 & $(3.505)^{* * *}$ \\
\hline
\end{tabular}

Note: $* * *, * *$ and $*$ represents the significance level in $1 \%, 5 \%$, and $10 \%$, respectively.

${ }^{3}$ There are $67,64,85$, and 83 firms, which are publicly traded and have full stock price information, included in the Top100 Brands list in 2010, 2011, 2012, and 2013, respectively. 
As seen in Table 1, CAAR differences between high brand value sample and the BIST100 index is $3.3 \%, 4.9 \%, 4.2 \%$, and $6.0 \%$ from the seventh to the tenth months, respectively. This indicates that the market starts to react positively to the brand value announcements 7 months after the event. Remarkably, there is no statistical difference in abnormal returns immediately after the event. Thus, one might think that investors respond with a much longer lag to the Top Brands rank, and take the scores into consideration when they subsequently rebalance their portfolios.

In order to investigate whether the stock returns of the companies listed in BrandFinance Turkey 100 are greater compared to the firms not listed in BrandFinance Turkey 100 list, we have conducted regression analysis with control variables of market capitalization and market-to-book ratio (See Table 2).

Table 2. Regression results for the impact of being in Top 100 brands list in Turkey

\begin{tabular}{ccccc}
\hline & \multicolumn{2}{c}{ Panel A } & \multicolumn{2}{c}{ Panel B } \\
\hline Variable & Coefficients & t-stats & Coefficients & t-stats \\
\hline BRAND & 0.065 & $(2.07)^{* *}$ & 0.068 & $(2.15)^{* *}$ \\
\hline CAP & & 0.000 & $(-0.74)$ \\
\hline MtB & & & 0.002 & $(0.77)$ \\
\hline D2010 & 0.395 & $(11.67)^{* * *}$ & 0.392 & $(11.34)^{* * *}$ \\
\hline D2011 & 0.141 & $(3.32)^{* * *}$ & 0.138 & $(3.17)^{* * *}$ \\
\hline D2012 & 0.085 & $(2.69)^{* * *}$ & 0.082 & $(2.54)^{* *}$ \\
\hline D2013 & -0.071 & $(-1.99)^{* *}$ & -0.069 & $(-1.94)$ \\
\hline R & 0.349 & & 0.351 & \\
\hline F Value & $54.73^{* * *}$ & & $39.18^{* * *}$ & \\
\hline
\end{tabular}

Notes: The regressions above are conducted using the whole sample of firms in Top Brands list in Turkey plus the firms included in BIST100 index in the related year over the 4 years; a total of 515 observations. Dependent variable CAR corresponds to the cumulative abnormal return of each firm 10 months after the Top 100 Brands list announcement. In the first regression (Panel A) CAR is regressed on the dummy variable BRAND which is coded " 1 " for the firms included in "Top 100 Brands" list and "0" otherwise by controlling the year-fixed effects. In the second regression (Panel B) CAP and MtB control variables are included in the model. ${ }^{* * *}, * *$ and $*$ denote the significance levels at $1 \%$, $5 \%$ and $10 \%$, respectively.

Table 2, Panel A presents the pooled regression of the cumulative stock returns in 10 months after the announcement on a set of dummy variables and a dummy variable taking the value of 1 if the firms listed in Top 100 Brands list and 0 otherwise during a 4 year period (2010-2013) plus the firms included in the BIST100 index in the related years (a total of 515 firm-years). According to the regression results, the dummy variable BRAND is statistically significant at 5\%. A coefficient of 0.065 indicates that companies in Top Brands list experience $6.5 \%$ higher returns than the firms not included in the list. When we allow for the impact of size and growth prospects (CAP and MtB 
respectively), the coefficient of BRAND does not significantly change which confirms our preliminary results (Panel B). Insignificant coefficient estimates of CAP and MtB indicates that other than market value and market-to-book ratio, being in Top Brands list is more influential on the future stock performance. Thus, H1 is accepted.

We utilized event-study analysis test $\mathrm{H} 2$, addressing the effect of brand value announcements of newly added stocks to the list. Table 3 demonstrates the AAR and CAAR values of the firms around the announcement date, which are newly added to the Top Brands list.

Table 3. Announcement window monthly abnormal returns for newly added firms

\begin{tabular}{ccccc}
\hline Period & AAR & t-stat & CAAR & t-stat \\
\hline 1 & -0.006 & $(-0.591)$ & -0.006 & $(-0.591)$ \\
\hline 2 & -0.047 & $(-2.933)^{* * *}$ & -0.054 & $(-2.637)^{* *}$ \\
\hline 3 & 0.026 & $(0.910)$ & -0.028 & $(-0.725)$ \\
\hline 4 & -0.016 & $(-0.558)$ & -0.043 & $(-0.876)$ \\
\hline 5 & 0.011 & $(0.699)$ & -0.033 & $(-0.714)$ \\
\hline 6 & -0.012 & $(-0.939)$ & -0.045 & $(-0.935)$ \\
\hline 7 & 0.010 & $(0.539)$ & -0.035 & $(-0.590)$ \\
\hline 8 & 0.005 & $(0.181)$ & -0.030 & $(-0.427)$ \\
\hline 9 & 0.015 & $(0.681)$ & -0.015 & $(-0.197)$ \\
\hline 10 & 0.026 & $(1.589)$ & 0.012 & $(0.153)$ \\
\hline
\end{tabular}

Note: $* * * * *$ and $*$ represents the significance level in $1 \%, 5 \%$, and $10 \%$, respectively. $\mathrm{N}=30$.

Remarkably, the newly added firms experience negative cumulative abnormal returns in most of the months in the event window, but the results are not statistically significant. There may be two alternative explanations for this observation. First, even though inclusion in the list discloses new information to the market, investors may be sceptical about the new firms and wait for the continuous inclusion to rebalance their portfolios. As brand valuation is mostly related to the intangibles, the reward might be obtained in the long run. Second, firm-specific characteristics of the newly added firms may cause controversial results due to small number of cases included in the analysis. Thus, H2 is not supported. Consequently, we also investigated the long- run performance of the newly added firms to reach a clearer conclusion. The results will be presented under heading of long-run performance of brand value portfolios.

In order to investigate whether brand value appreciation, depreciation, or a change in the firm's ranking is important, we also take into account this information to observe any return anomalies around the announcement month. Table 4 summarizes the event study findings of the firms who have a higher brand value or ranking compared to the previous year. 
Table 4. Announcement window monthly abnormal returns of the firms with higher brand values or rankings compared to the previous year

\begin{tabular}{ccccccc}
\hline & $\begin{array}{c}\text { Higher brand value compared } \\
\text { to the previous year } \\
\text { (in Dollars) }\end{array}$ & \multicolumn{2}{c}{$\begin{array}{c}\text { Higher brand value } \\
\text { compared to the previous } \\
\text { year (in Turkish Liras) }\end{array}$} & \multicolumn{2}{c}{$\begin{array}{c}\text { Higher brand ranking } \\
\text { compared to } \\
\text { the previous year }\end{array}$} \\
\hline Period & CAAR & t-stat & CAAR & t-stat & CAAR & t-stat \\
\hline 1 & 0.010 & $(0.919)$ & 0.003 & $(0.360)$ & -0.014 & $(-1.697)^{*}$ \\
\hline 2 & 0.018 & $(1.177)$ & 0.003 & $(0.257)$ & -0.028 & $(-2.085)^{* *}$ \\
\hline 3 & 0.010 & $(0.611)$ & 0.004 & $(0.292)$ & -0.006 & $(-0.723)$ \\
\hline 4 & 0.026 & $(1.318)$ & 0.022 & $(1.192)$ & -0.006 & $(-0.486)$ \\
\hline 5 & 0.029 & $(1.380)$ & 0.023 & $(1.254)$ & -0.009 & $(-1.139)$ \\
\hline 6 & 0.019 & $(0.866)$ & 0.023 & $(1.141)$ & -0.003 & $(-0.218)$ \\
\hline 7 & 0.052 & $(2.300)^{* *}$ & 0.049 & $(2.328)^{* *}$ & 0.009 & $(0.894)$ \\
\hline 8 & 0.083 & $(2.813)^{* * *}$ & 0.081 & $(3.032)^{* * *}$ & 0.044 & $(1.944)^{*}$ \\
\hline 9 & 0.052 & $(1.685)^{*}$ & 0.061 & $(2.214)^{* *}$ & -0.013 & $(-1.376)$ \\
\hline 10 & 0.076 & $(2.775)^{* * *}$ & 0.086 & $(3.394)^{* * *}$ & 0.013 & $(1.026)$ \\
\hline
\end{tabular}

Notes: $* * *, * *$ and $*$ represents the significance level in $1 \%, 5 \%$, and $10 \%$, respectively. There are 99 and 119 firms that have higher brand values relative to the previous year in term of Dollars and Turkish Liras, respectively. There are 88 brands in total whose ranks have risen.

The firms with higher brand value compared to the previous year earn positive and significant abnormal returns 7 months after the announcement. No statistical differences are observed in terms of currency exchanges (whether Dollars or Turkish Liras). Put differently, in 10 months period after the announcement, the cumulative abnormal returns reach up to $7.6 \%$ and $8.6 \%$ in the Dollars and Turkish Liras case, respectively. Thus, $\mathrm{H} 3 \mathrm{a}$ is accepted. However, if we consider rankings rather than values, no statistically significant difference in the stock prices is observed. Thus, H4a is rejected. Hence, rather than ranking, absolute increase in brand value is found to be more influential on stock prices.

In determining whether firms with lower brand values or rankings compared to the previous year experience negative abnormal stock returns, the event study methodology is utilized. Table 5 presents the event window abnormal returns of the firms whose brand values diminished or their rankings have fallen compared to the previous year.

As seen in Table 5, CAAR values are very small and statistically insignificant in most of the months in the event window considering the brand value depreciation in both Turkish Liras and Dollars. Thus, H3b is rejected. However, interestingly, the firms with lower ranks compared to the previous year experience significant positive abnormal returns 7 months after the announcement. Thus, $\mathrm{H} 4 \mathrm{~b}$ is rejected. Those findings are rather different to those by Brammer et al. (2009) who revealed that investors react negatively to the firms whose rankings have fallen. 
Table 5. Announcement window monthly excess returns of the firms with lower brand values or rankings compared to the previous year

\begin{tabular}{ccccccc}
\hline & $\begin{array}{c}\text { Lower brand value compared } \\
\text { to the previous year } \\
\text { (in Dollars) }\end{array}$ & \multicolumn{2}{c}{$\begin{array}{c}\text { Lower brand value compared } \\
\text { to the previous year } \\
\text { (in Turkish Liras) }\end{array}$} & \multicolumn{2}{c}{$\begin{array}{c}\text { Lower brand ranking } \\
\text { compared to } \\
\text { the previous year }\end{array}$} \\
\hline Period & CAAR & t-stat & CAAR & t-stat & CAAR & t-stat \\
\hline 1 & 0.004 & $(0.467)$ & 0.013 & $(1.303)$ & 0.022 & $(1.998)^{* *}$ \\
\hline 2 & -0.017 & $(-1.501)$ & -0.002 & $(-0.152)$ & 0.021 & $(1.541)$ \\
\hline 3 & -0.025 & $(-1.821)^{*}$ & -0.025 & $(-1.655)$ & 0.009 & $(0.604)$ \\
\hline 4 & -0.020 & $(-1.312)$ & -0.025 & $(-1.680)^{*}$ & 0.024 & $(1.369)$ \\
\hline 5 & -0.021 & $(-1.331)$ & -0.026 & $(-1.549)$ & 0.029 & $(1.483)$ \\
\hline 6 & -0.004 & $(-0.176)$ & -0.016 & $(-0.710)$ & 0.033 & $(1.638)$ \\
\hline 7 & 0.013 & $(0.554)$ & 0.007 & $(0.280)$ & 0.068 & $(3.074)^{* * *}$ \\
\hline 8 & 0.033 & $(1.343)$ & 0.024 & $(0.887)$ & 0.083 & $(3.729)^{* * *}$ \\
\hline 9 & 0.013 & $(0.540)$ & -0.012 & $(-0.473)$ & 0.040 & $(1.812)$ \\
\hline 10 & 0.024 & $(0.946)$ & -0.006 & $(-0.233)$ & 0.053 & $(2.351)^{* *}$ \\
\hline
\end{tabular}

Notes: $* * *, * *$ and $*$ represents the significance level in $1 \%, 5 \%$, and $10 \%$, respectively. There are 93 , 73 firms that have higher brand values relative to the previous year in terms of Dollars and Turkish Liras, respectively. There are 107 brands in total whose ranks have risen.

\subsection{Long-run performance of brand value portfolios}

To assess whether inclusion in the Top 100 Brands list generates abnormal returns in the long run, we constructed various portfolios and compared their cumulative abnormal returns with a proxy of a full market benchmark portfolio, BIST100 Index.

First of all, we formed both equal-weighted and value-weighted portfolios for all firms included in the BrandFinance Turkey 100 ranking list, by updating the portfolio every year after the announcement, starting from the year 2010 up to 2014, covering 52 months. Value-weighted portfolios are formed by dividing each firm's individual brand value by the sum of all firms' brand values in the portfolio for each year. Thus, the weight of each brand is updated annually according to the changes in the brand values. Figure 1 depicts our findings.

The estimation of the long-run performance of a Top Brands portfolio gives us an important implication that Top Brands portfolio outperforms the market index almost in every month in terms of CAAR values. CAARs for the equal- and value-weighted portfolios reaches up to approximately $18 \%$ and $22 \%$ in the 52 -months period, respectively, if we ignore transaction costs.

Higher performance may be accompanied by higher risk. To see the actual reward of any portfolio, risk-adjusted performance should be assessed. Table 6 summarizes and compares the risk-adjusted performances of different Top Brands portfolios. 


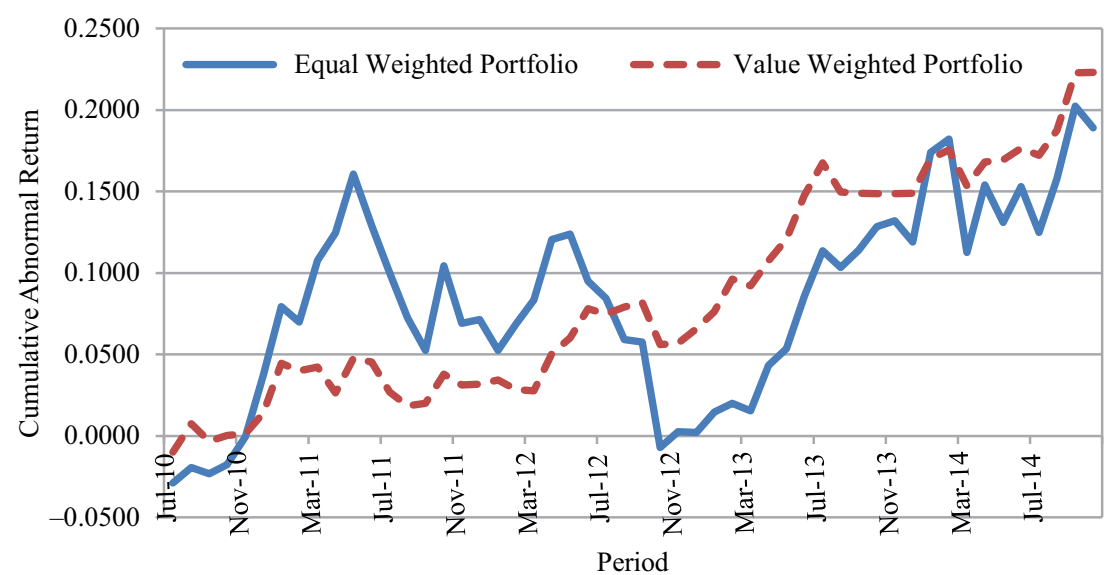

Fig. 1. Long run performance of the brand portfolios

Table 6. Long run risk-adjusted performance of all sample and benchmark portfolio

\begin{tabular}{ccccccccc}
\hline & \multicolumn{3}{c}{ Equal-weighted portfolio } & \multicolumn{2}{c}{ Value-weighted portfolio } & \multicolumn{2}{c}{ BIST100 index } \\
\hline $\begin{array}{c}\text { Holding } \\
\text { period }\end{array}$ & Sharpe & Treynor & $\begin{array}{c}\text { Jensen's } \\
\text { Alpha }\end{array}$ & Sharpe & Treynor & $\begin{array}{c}\text { Jensen's } \\
\text { Alpha }\end{array}$ & Sharpe & Treynor \\
\hline 1 Year & 0.0813 & -0.0059 & 0.0050 & 0.1517 & -0.0105 & 0.0005 & -0.1632 & -0.0110 \\
\hline 2 Years & 0.0080 & 0.0006 & 0.0021 & 0.0192 & 0.0014 & 0.0030 & -0.0246 & -0.0017 \\
\hline 3 Years & 0.0289 & 0.0021 & 0.0023 & 0.0555 & 0.0038 & 0.0041 & -0.0090 & -0.0006 \\
\hline 4 Years & 0.0161 & 0.0012 & 0.0025 & 0.0280 & 0.0020 & 0.0035 & -0.0249 & -0.0017 \\
\hline 5 Years & 0.0216 & 0.0016 & 0.0032 & 0.0310 & 0.0022 & 0.0041 & -0.0336 & -0.0023 \\
\hline
\end{tabular}

Note: This table demonstrates the risk-adjusted performances of various portfolios in the long run. Holding periods corresponds to the period between two brand value announcements rather than actual years. The total holding period starts in July 2010 and ends in October 2014, and covers 52 months.

Table 6 reveals that both equal-weighted and value-weighted Top Brands portfolios outperform the market according to all of the risk-adjusted measures. That is, investors will be able to beat the market in the long run by forming portfolios, including high brand value firms which is consistent with the findings of Madden et al. (2006) and Hsu et al. (2013). However, the value-weighted portfolio performs better than the equal-weighted portfolio almost in all of the holding periods, which implies that investing more in the high brand value firms is a relatively better investment strategy in the long run regarding the risk-adjusted excess returns. Thus, H5a is supported.

In order to investigate the value relevance of brand value announcements on stock returns for the newly listed firms, we formed both equal and value-weighted portfolios starting from the year 2011 up to 2014 . We proposed an investment strategy by investing solely in the newly listed firms and updating the portfolio every year. In other words, after each announcement, we added newly listed firms to our portfolio and dropped the remaining firms. Our sample consists of 35 newly listed firms in total. Figure 2 depicts the long-run performance of the newly listed firms. 


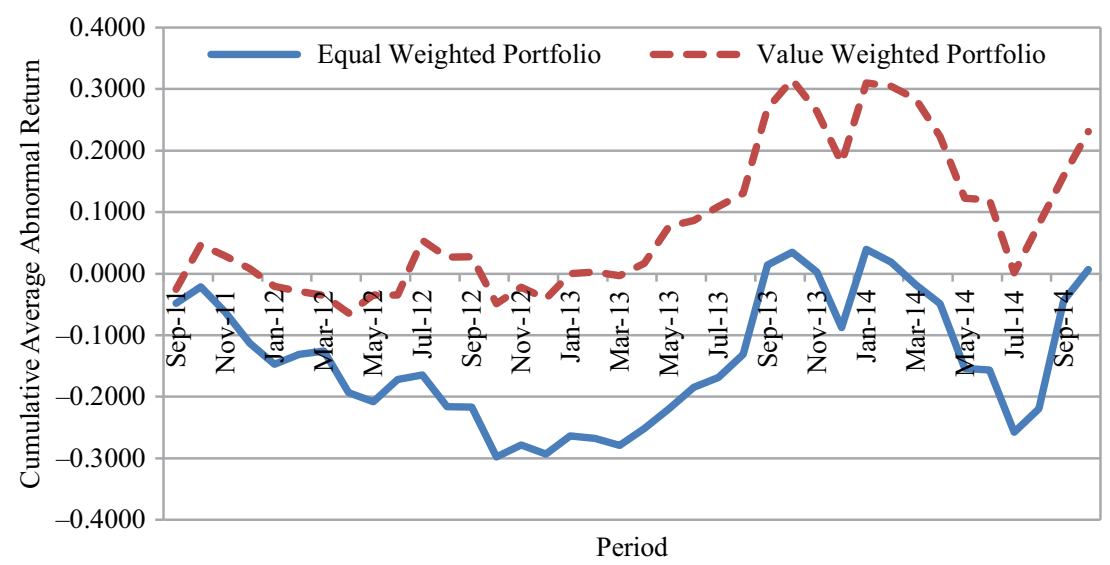

Fig. 2. Long run performance of the newly listed firms' portfolio

According to the Figure 2, there is a large gap between the cumulative abnormal returns of equal-weighted and value-weighted portfolios. Investing in newly listed firms with equal weights underperforms the market in the long run. However, the performance of the value-weighted portfolio is far better than the equal-weighted portfolio and the benchmark index in the long run. Additionally, we also compared and summarized the risk-adjusted returns of the portfolios in Table 7, to see the actual reward in response to the different volatility measures.

Empirical evidence obtained for the newly added firms tells us a similar story. According to all of the risk-adjusted performance metrics, value-weighted portfolios outperform both equal-weighted and market portfolios. However, equal-weighted portfolios of the newly added firms perform worse than the value-weighted portfolios and the market. The implication for this is that investors are better off only if they form value-weighted portfolios. So, H5b is not supported.

Table 7. Long run risk-adjusted performance of newly listed firms' portfolios

\begin{tabular}{ccccccccc}
\hline & \multicolumn{2}{c}{ Equal-weighted portfolio } & \multicolumn{2}{c}{ Value-weighted portfolio } & \multicolumn{2}{c}{ BIST100 index } \\
\hline $\begin{array}{c}\text { Holding } \\
\text { period }\end{array}$ & Sharpe & Treynor & $\begin{array}{c}\text { Jensen's } \\
\text { Alpha }\end{array}$ & Sharpe & Treynor & $\begin{array}{c}\text { Jensen's } \\
\text { Alpha }\end{array}$ & Sharpe & Treynor \\
\hline 1 Year & -0.1001 & -0.0081 & -0.0189 & 0.1554 & 0.0136 & 0.0062 & 0.1224 & 0.0091 \\
\hline 2 Years & -0.0334 & -0.0026 & -0.0078 & 0.1597 & 0.0128 & 0.0062 & 0.0908 & 0.0061 \\
\hline 3 Years & -0.0287 & -0.0026 & -0.0045 & 0.0720 & 0.0067 & 0.0040 & 0.0310 & 0.0022 \\
\hline 4 Years & 0.0133 & 0.0013 & 0.0003 & 0.0864 & 0.0083 & 0.0062 & 0.0136 & 0.0009 \\
\hline
\end{tabular}

Notes: This table demonstrates the risk-adjusted performances of various portfolios in the long run. Holding periods correspond to the period between two brand value announcements rather than actual years. The total holding period starts in September 2011 and ends in October 2014, and covers 38 months. 


\section{Conclusions}

This paper investigates the association between brand value measures and stock performance of the firms that are listed in Borsa Istanbul and provide additional support on understanding how intangible assets (brand value) contribute to long-term financial performance. It contributes to the literature by demonstrating the interface between finance and marketing. Using an event study methodology, we examined the stock-price impacts of 299 brand value announcements within the years of 2010-2014 by using BrandFinance Turkey's 100 ranking list as a data source. Overall, the findings reveal that the market positively reacts to the brand value announcements; however it takes a long time to get market reaction, which means that the market rewards the firms which are listed in the Top Brands Portfolio and the ones with higher brand value in the relatively long run. Remarkably, the firms newly entering the list are likely to experience negative cumulative abnormal returns in most of the months in the event window; however the results are not statistically significant. A supplementary finding of the study pertains to the wealth maximization strategy. Accordingly, the findings suggest that the adoption of an investment strategy, which argues consistent investment in the firms listed firms in BrandFinance Turkey lead the investors earn higher returns when they form both equal-weighted and value-weighted portfolios. However, same conclusion is not valid when we consider only the newly listed firms.

In terms of practical implications, the findings of this study might be noteworthy for marketing managers to enhance their brand names and increase the market value of the firms by investing more in branding activities. That is, brand value investments are expected to pay off in terms of financial returns, which will encourage managers to invest more in brand value enhancing activities. In addition to marketing perspective, the current study offers practical implication regarding individual investors. Individual investors should acknowledge that the funds listed in top brands list could outperform conventional funds since they provide important information concerning the brand awareness of companies that is not fully reflected in security prices. Such that, the firms' brand values and their ranks in Top Brands list could be used as a proxy and valuable guide in the selection of stocks as they signal the future financial performance of those stocks. This type of finding is clearly a valuable resource for the foreign investors who are willing to invest in emerging markets as well. Those markets become especially more attractive to international investors because they offer a combination of rapid growth of investment opportunities and higher volatility. However, while there is no clear best practice for the valuation of securities in emerging markets, this situation raises an ultimate question for investors on how to allocate the stocks in the overall investment process. One might argue that the foreign investors could take into account the information contained in Top Brands list while making their stock selections. As investors prefer holding shares in well-known companies (i.e. familiarity bias), brand value could be used as a remarkable indicator in assessing the performance and the risk of the companies.

This study is not without its limitations. We had only access to 4 years of brand value rankings. A more complete brand value ranking history for each brand would no doubt 
yield even greater insights and more robust conclusions given the fact it takes years to create brand equity. Another limitation pertains to the usage of BrandFinance valuation methodology and the findings derived from the study are overall restricted with the credibility of those estimates. Future studies could validate the findings with the metrics of other brand valuation companies.

Although we do not assure cause-effect relationship, this study extends our understanding of the important role of brand values and the announcement of brand values in future stock performance. Future research might extend these findings by including other intangible assets such as market share and customer satisfaction as proxies in maximizing future returns of stockholders and thereby increasing the market value of the firm. Future research could also utilize some other performance measures such as ROE, ROI and Tobin $\mathrm{Q}$ ratio in addition to the abnormal stock returns. It also remains an interesting area to explore the relative importance of brand values within different sectors.

\section{References}

Aaker, D. 1991. Managing brand equity. Capitalizing on the value of a brand name. New York: Free Press.

Aaker, D. A.; Jacobson, R. 1994. The financial information content of perceived quality, Journal of Marketing Research 31(2): 191-201. http://dx.doi.org/10.2307/3152193

Baharadwaj, S.; Tuli, K. R.; Bonfrer, A. 2011. The impact of brand quality on shareholder wealth, Journal of Marketing 75(5): 88-104. http://dx.doi.org/10.2139/ssrn.1843503

Barth, M. E.; Clement, M. B.; Foster, G; Kasznik, R. 1998. Brand values and capital market valuation, Review of Accounting Studies 3: 41-68. http://dx.doi.org/ 10.1023/A:1009620132177

Belo, F.; Lin, X.; Vitorino, M. A. 2014. Brand capital and firm value, Review of Economic Dynamics 17(1): 150-169. http://dx.doi.org/10.1016/j.red.2013.05.001

Brammer, S. J.; Brooks, C.; Pavelin, S. 2009. The stock performance of America's 100 Best Corporate Citizens, The Quarterly Review of Economics and Finance 49(3): 1065-1080.

http://dx.doi.org/10.1016/j.qref.2009.04.001

BrandFinance. 2013. Explanation of the methodology [online], [cited 18 June 2015]. Available from Internet: http://brandirectory.com/methodology

Calderon, H.; Cervera, A.; Molla, A. 1997. Brand assessment: a key element of marketing strategy, Journal of Product \& Brand Management 6(5): 293-304.

http://dx.doi.org/10.1108/10610429710179462

Cobb-Walgren, C. J.; Ruble, C. A.; Donthu, N. 1995. Brand equity, brand preference, and purchase intent, Journal of Advertising 24(3): 25-40.

http://dx.doi.org/10.1080/00913367.1995.10673481

Copraro, A. J.; Srivastava, R. K. 1997. How do reputations affect corporate performance?: Has the influence of financial performance on reputation measures been overstated?, Corporate Reputation Review 1(1): 86-92. http://dx.doi.org/ 10.1057/palgrave.crr.1540023

Conchar, M. P.; Crask, M. R.; Zinkhan, G. M. 2005. Market valuation models of the effect of advertising and promotional spending: a review \& meta-analysis, Journal of the Academy of Marketing Science 33(4): 445-460. http://dx.doi.org/10.1177/0092070305277693

Davis, J. A. 2010. Competitive success, How branding adds value. John Wiley \& Sons.

Day, G.; Fahey, L. 1988. Valuing market strategies, Journal of Marketing 52(3): 45-57.

http://dx.doi.org/10.2307/1251449 
de Mortanges, C. P.; Van Riel, A. 2003. Brand equity and shareholder value, European Management Journal 21(4): 521-527. http://dx.doi.org/doi:10.1016/S0263-2373(03)00076-8

DeBondt, W. F.; Thaler, R. 1985. Does the stock market overreact?, The Journal of Finance 40(3): 793-805. http://doi.org/10.2307/2327804

Denis, D. K.; McConnell, J. J.; Ovtchinnikov, A. V.; Yu, Y. 2003. S\&P 500 index additions and earnings expectations, Journal of Finance 58(5): 1821-1840. http://dx.doi.org/10.2139/ssrn.329543

Dhillon, U; Johnson, H. 1991. Changes in the Standard and Poor's 500 list, Journal of Business 64(1): 75-85. http://dx.doi.org/10.1086/296526

Dutordoir, M.; Verbeeten, F. H. M.; DeBeijer, D. 2015. Stock price reactions to brand value announcements: magnitude and moderators, International Journal of Research in Marketing 32(1): 34-47. http://dx.doi.org/doi:10.1016/j.ijresmar.2014.08.001

Edmans, A. 2011. Does the stock market fully value intangibles? Employee satisfaction and equity prices, Journal of Financial Economics 101(3): 621-640.

http://dx.doi.org/doi:10.1016/j.jfineco.2011.03.021

Eng, L. L.; Keh, H. T. 2007. The effects of advertising and brand value on future operating and market performance, Journal of Advertising 36(4): 91-100.

http://dx.doi.org/ 10.2753/JOA0091-3367360407

Fama, E. F. 1998. Market efficiency, long-term returns, and behavioral finance, Journal of Financial Economics 49(3): 283-306. http://dx.doi.org/ doi:10.1016/S0304-405X(98)00026-9

Fama, E. F.; Miller, M. H. 1972. The theory of finance. Illinois, Hinsdale: Dreyden Press.

Himme, A.; Fischer, M. 2014. Drivers of the cost of capital: the joint role of non-financial metrics, International Journal of Research in Marketing 31(2): 224-238.

http://dx.doi.org/10.1016/j.ijresmar.2013.10.006

Hsu, F. J.; Wang, T. Y.; Chen, M. Y. 2013. The impact of brand value on financial performance, Advances in Management \& Applied Economics 3(6): 129-141.

Jensen, M. 1968. The performance of mutual funds in the period 1945-1964, Journal of Finance 23(2): 389-416. http://dx.doi.org/10.2139/ssrn.244153

Johansson, J. K.; Dimofte, C. V.; Mazvancheryl, S. K. 2012. The performance of global brands in the 2008 financial crisis: a test of two brand value measures, International Journal of Research in Marketing 29(3): 235-245. http://dx.doi.org/ 10.1016/j.ijresmar.2012.01.002

Kallapur, S.; Kwan, S. Y. 2004. The value relevance and reliability of brand assets recognized by UK firms, The Accounting Review 79(1): 151-172. http://dx.doi.org/10.2308/accr.2004.79.1.151

Keller, K. L. 2003. Strategic brand management: Building, measuring, and managing brand equity. Prentice-Hall.

Kerin, R. A.; Sethuraman, R. 1998. Exploring the brand value-shareholder value nexus for consumer goods companies, Journal of the Academy of Marketing Science 26(4): 260-273.

http://dx.doi.org/10.1177/0092070398264001

Lane, V.; Jacobson, R. 1995. Stock market reactions to brand extension announcements: the effects of brand attitude and familiarity, Journal of Marketing 59(1): 63-77.

http://dx.doi.org/10.2307/1252015

Madden, T. J.; Fehle, F.; Fournier, S. 2006. Brands matter: an empirical demonstration of the creation of shareholder value through branding, Journal of the Academy of Marketing Science 34(2): 224-235. http://dx.doi.org/10.1177/0092070305283356

Merton, R. C. 1987. A simple model of capital market equilibrium with incomplete information, The Journal of Finance 42: 483-510. http://dx.doi.org/10.1111/j.1540-6261.1987.tb04565.x

Osinga, E. C.; Leeflang, P. S. H; Srinivasan, S.; Wieringa, J. E. 2011. Why do firms invest in consumer advertising with limited sales response? A shareholder perspective, Journal of Marketing 75(1): 109-124. http://dx.doi.org/10.1509/jmkg.75.1.109 
Peterson, R. A.; Jeong, J. 2010. Exploring the impact of advertising and R\&D expenditures on corporate brand value and firm-level financial performance, Journal of the Academy of Marketing Science 38(6): 677-690. http://dx.doi.org/ 10.1007/s11747-010-0188-3

Sharpe, W. 1994. The sharpe ratio, The Journal of Portfolio Management 21(1): 49-58. http://dx.doi.org/10.3905/jpm.1994.40950

Tiwari, M. K. 2010. Separation of brand equity and brand value, Global Business Review 11(3): 421-434. http://dx.doi.org/ 10.1177/097215091001100307

Treynor, J. 1965. How to rate management of investment funds, Harvard Business Review 43(1): 63-75. http://dx.doi.org/10.1002/9781119196679.ch10

Verbeeten, F. H. M.; Vijn, P. 2010. Are brand-equity measures associated with business-unit financial performance? Empirical evidence from the Netherlands, Journal of Accounting, Auditing and Finance 25(4): 645-671. http://dx.doi.org/10.1177/0148558X1002500408

Wang, D. H. M.; Chen, P. H.; Yu, T. H. K.; Hsiao, C. Y. 2015. The effects of corporate social responsibility on brand equity and firm performance, Journal of Business Research 68(11): 2232-2236. http://dx.doi.org/10.1016/j.jbusres.2015.06.003

Yeung, M.; Ramasamy, B. 2008. Brand value and firm performance nexus: further empirical evidence, Journal of Brand Management 15: 322-335.

http://dx.doi.org/10.1057/palgrave.bm.2550092

Pinar BASGOZE works as an Associate Professor (Marketing) Lecturer in Hacettepe University, Faculty of Economics and Administrative Sciences, Department of Business. Her recent research interests include the areas of marketing management, brand strategies, consumer behaviour and promotional strategies that are published in scientific journals including Total Quality Management and Business Excellence and book chapters.

Yilmaz YILDIZ is currently a $\mathrm{PhD}$ research assistant in Faculty of Economics and Administrative Sciences, Department of Business Administration at Hacettepe University. His recent research interests focus on pension finance, foreign investments, market efficiency and global valuation that are published in scientific journals as well as international conferences.

Selin METIN CAMGOZ works as an Associate Professor at the Department of Business Administration, Hacettepe University, Turkey. Her recent interests include behavioural finance, organizational behaviour, heuristics and biases in decision making processes, investor psychology and leadership. She has published several papers in journals including Journal of Business Research, Entrepreneurship \& Regional Development: An International Journal, and Social Behaviour and Personality. 